\title{
The Influence of Human Resource Practices on the Retention of Core Employees
}

\author{
SHEHNAZ SAHIB ZADA \\ Lecturer, Institute of Business Studies and Leadership \\ Abdul Wali Khan University, Mardan \\ doctorsherry28@yahoo.com \\ DR. SHAHID JAN \\ Associate Professor, Islamia College University, Peshawar \\ shahidjan@icp.edu.pk \\ SYED IMRAN KHAN \\ Lecturer, Institute of Business Studies and Leadership \\ Abdul Wali Khan University, Mardan \\ syedzadaimran@awkum.edu.pk \\ MUHAMMAD ABDUL HASEEB \\ PhD Scholar, Institute of Management Sciences, Peshawar \\ haseeb@awkum.edu.pk
}

\begin{abstract}
The retention of core employees is one of the challenges many of business organizations facing today. For many organizations, strategic staffing has become a concern because the ability to hold on to highly talented core employees can be crucial to future survival. This empirical study examined the current human resource management (HRM) practices of Higher education institution of Khyber Pakhtunkhwa in the retention of their core employees. In particular, the research identified the core elements of HRM practices, which strongly influence the decision for core employees to stay. With the rapid growth and introduction of new public and private sector universities in Khyber Pakhtunkhwa, it became difficult to retain employees. The current study focuses on employees of both public and private sector universities in order to extract information about employee choice and critically examines HR practices and factors, which may influence employees to stay and work for organization. Analyzing the existing Human Resources Management literature, there are very few studies have been conducted regarding Human Resource Management practices on retention of core employees. This raises uncultivated issues such as: which factor of HRM, influences retention of core employees in higher education institution of Khyber Pakhtunkhwa. These unexplored and uncultivated issues will be the focal point of this study. Furthermore, this study will explore \& press forward the HRM literature on the rising trends of the 21st century.
\end{abstract}

Keywords: Human Resource Practices, Retention, OLS

\section{Introduction}

Today most of the Organizations relentlessly struggle to gain essential inclination: most of the organizations facing global competition, under constant pressure to step up the pace, to introduce new products, gain new technology, and cope up with demographic changes, and also, they must make an effort to employ trends towards 
society that is based on information and services (Kane 2000). Due to this riotous and challenging business environment, one of the hurdles that confront the business organizations is the retaining of core employees. Organizations and business inclination now days depend upon knowledge base human capital and this human capital plays an important role in organization affectivity and productivity. Organizations are contending for the talented employees (Porter 2001).To survive organizational downsizing, many new organizations put emphasis on business management practices, in order to successfully retain \& motivate high talented employees (Clark, 2001).

To retain highly talented core employees for the future survival of organization, many organizations consider strategic staffing as an important issue. (Ettore, 1997; Whitner 2001). Employees quitting the organization are expensive, since employee leaving an organization means, that organization have lost investment in talent expansion and also increase in the budget of recruiting and understanding new talent (Eskildsen and Nussler 2000). In many Organizations the relationships between employees and management are the outcomes of their HR policies and practices, or organization may purely formulate those practices that compact with the ongoing requirements problems. These practices comprise of the following factors:

- T \& D (Training and Development).

- OHS (Occupational health and safety).

- HRIS (Human Resource Information System).

- IR (Industrial Relation).

- Employees Recruitment \& Selection.

- Performance Management.

- Remuneration system.

- Impact of recent legislation (Oakland \& Oakland, 2001).

According to Ettorre (1997) and Davies (2001) yearly turn over (employee leaving the organization) at reputable organizations is only six percent. The costs of recruiting new talent or employees usually shoot up to 1/4th of a person's annual pay. An organization with fifty thousand recruits may cost an estimated amount of $\$ 18$ million/annum. According to a study released by Accenture (2001), 68 percent of the global business leaders and managers believe that retaining the current talent for the survival of organization is more important than acquiring 'new blood'. In fact now a day's more organizations are realizing that retaining of skilled human resource represents a competitive advantage and deal it with as strategic concern. (Walker 2001).

Organization may effectively keep critical employees, if the adopt and maintain an effective total retention strategy with the help and support of parallel HR programs.

This research inspects the current HR factors and practices which deal with the retaining of core employees in public and private sector universities in Khyber Pakhtunkhwa. It investigates the association between human resource practices and retention of core employees, and furthermore it categorizes those elements of HR practices, which have positive and strongly influence core employees to continue within the organization. This is causal study and the outcomes of this research may help in the development and growth of an effective and productive Human Resource retention program for universities.

\subsection{Purpose of the study}

The basic intention of this study is to seek \& explore the existing HR practices and its association with the retention of core employees in Higher education sectors in Khyber Pakhtunkhwa. Along with this, the study is aim to recognize those elements 
of HR practices, which strongly influence the decision for core employees to stay in the organization. The outcome of this research will have positive impact on organization, because the required result will help in establishing and maintaining effective HRM retention programs. For organizations employee's retention is a highly important strategic tool. Because using it as strategic tool, it helps organization to select those human resources who will become devoted to their organization and also enhance the employers' ability to maintain, motivated and vastly skill employees.

\subsection{Problem statement}

In modern competing world, now a day's organizations rely upon competent and talented employees, but in many cases due to arrival of new public and private universities in education sector in Khyber Pakhtunkhwa, most of the universities faces high turnover. To address this problem thesis will try:

"To identify the causes of high employee's retention in public and private sectors universities of Khyber Pakhtoonkhwa and to determine those factors that positively contribute towards it".

\subsection{Research questions}

- Is there any association between HR practices and retention?

- Which Human Resource factors will most influence the decision of employees to stay in the organization?

- What is a core employee?

2. Literature Review

\subsection{Human Resource Management Factors Influencing Retention}

Maintaining a high quality human work force, it is pivotal for the firms to have better HR systems. Previous studies shows that, the attaining of best quality work and achievement of better financial performance for organization, can be achieved by following and implementing progressive HRM practices such as T\&D, Reward sharing \& Compensation, studies reveal that these practices can lead to reduce or maintain employees turnover and absenteeism (Snell \& Dean 1992, Ichniowski, Shaw \&Prenushi 1997; Arthur1994;Delaney \&Huselid 1996; Youndt \& Snell 1995; MacDuffie 1995; Meyer \&Allen 1991; Solomon 1992). Regarding these three variables, one might argue that reward and recognition, compensation and employees training and development are known indicators of employee's retention. But this study looks at the role of HRM practices i.e. reward and recognition, compensation and training and development separately it will high-light the importance and preference of each practices later in literature review.

\subsection{Training and Career Development}

In the success of organization, training plays an important role. (Bassi and Van Buren 1999). The levels and consistency in training and employee turnover is inversely related: the decrease in the amount of training will result in higher level of turnover. This prospect is based on an argument that higher the investment on training, the longer the employee will stay with the firm. A recent study by Frazis et al. (1998) indicated that those organizations have low turn-over, who spent $59 \%$ of training time in formal training, in contrast those organizations are facing high turn-over who spent $18 \%$. For instance, poor job performance maybe because of scarcity of proper training, which results in higher job turnover. Those Organizations, which have pragmatic perceptive regarding the fundamental nature of training, will have high success ratio and less job turnover. Contrary to these findings and investigations, regarding positive impact of $(\mathrm{T} \& \mathrm{D})$ on turnover, some of the researchers are of the view that $(T \& D)$ affect organizational commitment and job satisfaction, which in 
result change or affect staff retention ( Zhang \& Lam, 2003; Lowry et al., 2002; Pratten, 2003; Taylor et al.,2001). According to Harris (1990), he assume that most of the organizations try to lessen job turnover through the stipulation of training programs to its constituent and find training programs as ways to broaden employees' skills and techniques. While according to, Veum (1997) his research regarding impact of training on new recruits reveal weak evidence, that training lessen job turnover. Another investigation carried out by Peter \& Elias state that training does not provide help in lessening the job turnover. likewise, Bishop (1991) establish that there is no significant and considerable relationship between job turnover and required training programs. Salipante \&Goodman (1976) revealed that contribution and implementation of training program alone had no considerable effect on employee retention or job turnover, \& Green et al. (2000) concluded that available training practices does not have any major effect on job mobility. According to the findings of, Sheng (2003) state that those individuals are more likely to leave organization, which are more contented and have access to training programs. One probable cause for this action could be that individuals attend training programs to increase their job mobility \& employment opportunity. On the other hand, Reddy (1996) recommended that there is an association between job turnover $\&$ the availability of training programs, but the exact scenery of this association is blurred.

\subsection{Reward and recognition}

According to a study by Mercer (2003) Rewards plays an important role in maintaining of employees. On the basis of (QBP) Quality Based Performance employees are rewarded. When employee achievement is acknowledged, the level of motivation improves. As long as employees hard work, and inputs are acknowledged and valued, they will stay with the organization (Davies2001). According the talent management programs, employers are more blinders towards using of rewards. To distinguish the rewards of the top performer it is progressively more pivotal for the organization to effectively use their reward budget. Some researchers emphasize on the issue of recognition and consider it as most important tool for employee motivation. (Appelbaum \&Kamal 1998; Dutton 1998; David \& Grawitch 2006; Saunderson 2004), giving distinctiveness to their employees and giving meaningful and productive tasks. (Mow 1987; Morin 1996, 2001).

Recognition is articulated in two ways. The primary type of judgment, what we referred as the 'benefit judgment', which is define by supervisory personnel, clients or subordinates, and addresses the social, economic and technical benefits of the employee's work. And the second type of judgment is The 'beauty judgment', which is mainly issued by peers, who are in a better position than anyone else to judge the quality of work performed and the effort put in by the person. While passing the judgments, this group of people distinguishes the person performance according to his performance at his workplace. Better performers are rewarded with special benefits, which include bonuses, pay premiums and stock options. (clot, 1999). One of the common factor that affects employees' satisfaction \& their likeliness to quit organization were dissatisfaction with rewards \& recognition (Ramlal,2003). Finally, by giving consideration to employee job satisfaction and low retention, through reward and recognition, it also has a positive impact on organizational productivity and high performance (Applebaum \& Kamal 2000).

\subsection{Compensation}

Compensation "is the most critical issue when it comes to attracting and keeping talent" (Willis 2000, p. 20).A fair remuneration or compensation is the foundation stone and agreement between employers and employees. money can influence 
behavior that's the fundamental hypothesis, what the researchers now a days anticipate (ParkerandWright2001). Furthermore, compensation promotes on-the-job learning (Lippit1997) and consider as a structure lumpo flearning organizations (Griego, Geroy and Wright2000). In organizations recruitment and retention of employees are related to wages or in some other way influence by wages and compensation. (Highhouse et al., 1999; Parker and Wright 2001; Rynes and Barber 1990; Williams and Dreher 1992). So a good wages offered by the organization play important role in staffing procedure. Nevertheless, previous studies show that pay by it self-will not be sufficient to retain people. It is not essential that organization offering high pay will help in maintaining the employees, but low pay will definitely drive employees out the door. Eventually, in organization employees like to stay because of their colleagues and co-workers and they enjoy challenging tasks that makes them better at what they do.

\subsection{Turnover Intention}

According to Tett and Meyer (1993, p. 262) Cognizant and purposeful determination to quit organization or firm is said to be turnover intention. The required Policies and practices, that organization uses to prevent valuable employees from quitting their job refers to Employee retention. For the utmost time organizations persuade employees to remain in the organization by taking some critical steps. It is essential for the employer to hire knowledgeable people in organization. Retention is even more important than hiring new knowledgeable employees. Because the amount of cost related to turn over of key staff (Ahlrichs, 2000). Employees turnover overheads can come up with issues such as induction expenses, advertisements of job, test and interview procedures, reference checks, safety issues, provisional worker expenses, rearrangement costs, \& formal training expenses (Roodt \& Kotze, 2005). Other concealed costs such as, clients negative image about the organization, lesser moral of employees, and above all, the loss of precious organizational knowledge. That's the reason that many organizations today try their best to maintain top talent at their workplace. To make certain that employee's turn over always remain low, Managers have to put a lot of effort, because top employees are critical to organization success, Meaghan et al.,(2002).

\section{6: $\quad$ Theoretical Framework}

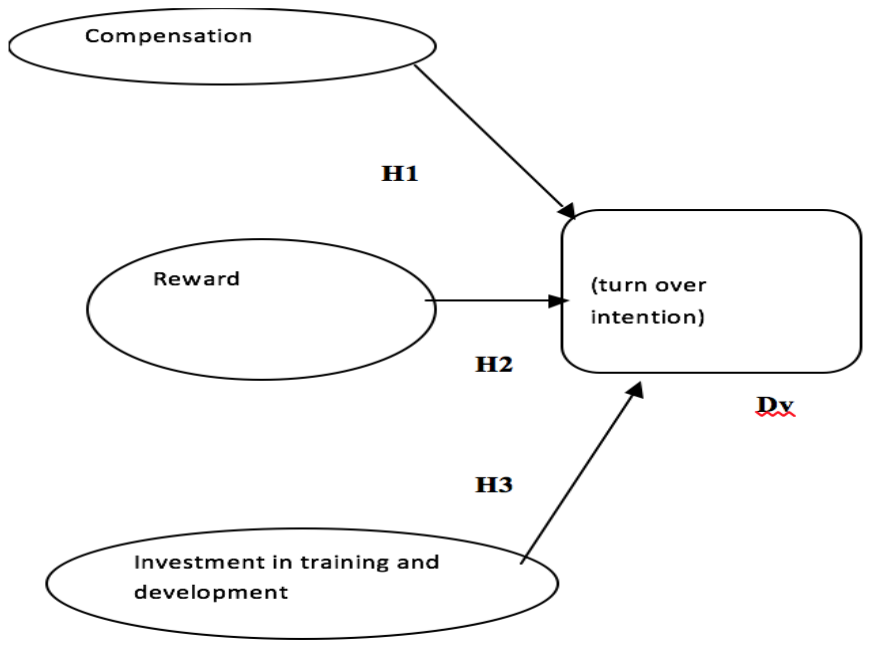




\subsection{Hypotheses}

From above conceptual frame work, the following hypotheses has been developed, which will be tested in this study,

H1: There is significant relationship between employees Compensation \& employee's turnover intention

Hla: There is significant relationship between employees Compensation \& Employees turnover intention in public sector universities.

H1b: There is significant relationship between employees Compensation \& Employees turnover intention in private sector universities.

H2: There is significant relationship between Reward \& employee's turnover intention.

H2a: There is significant relationship between Reward \& Employee's turnover intentions in public sector universities.

H2b: There is significant relationship between Reward \& Employee's turnover intentions in private sector universities

H3: There is significant relationship between employee's Training \& Development and employee's turnover intention.

H3a: There is significant relationship between employee's Training \& Development and employee's turnover intention in public sector universities.

H3b: There is significant relationship between employee's Training \& Development and employee's turnover intention in private sector universities.

H4: the impact of HRM practices implies differ across public and private sector universities.

3. Methodology

By using quantitative approach, it is unavoidably that the cram will be hauling out causal research. All variables will be empirically examined using statistical technique, in order to prove the cause and effect affiliation between employee withholding in organization and the independent factors, i.e. investment in training in development, compensation and reward \&recognition. In this research, in order to get the primary data, a questionnaire consisting four main variables, namely compensation, investment in employees training \& development, employees Reward $\&$ Recognition and turnover intentions. The questionnaire would be distributed to sampling amount of teaching staff in public and private sectors universities of Khyber Pakhtunkhwa..University teaching staff will fill up the required questionnaire and later the responses will be tested through SPSS software. This study also utilized secondary sources of data such as online records from internet. The journal critiques of appropriate study field are adopted from Google scholar, Social Science Research Network. Emerald, Proquest Database, ebscohost and Science Direct database. The population in this study is comprised of faculty members of public and private sector universities in Khyber pukhtun Khwa. In this research, the sampling locations of respondents are faculty members of public and private sectors universities of Khyber Pakhtunkhwa. Using questionnaire, questions were asked from respondents about key variables i.e. reward and recognition, compensation, training and development, and turnover intention. A total of 25 questions were asked on five point Likert scale. 


\section{4. $\quad$ Empirical Results}

\subsection{Empirical Results of Public sector Universities}

\begin{tabular}{cllll}
\hline \multicolumn{4}{c}{ Model Summary } \\
\hline Model & $\mathrm{R}$ & R Square & $\begin{array}{l}\text { Adjusted } \\
\text { Square }\end{array}$ & $\begin{array}{c}\text { R Std. Error of } \\
\text { the Estimate }\end{array}$ \\
\hline \begin{tabular}{lllll} 
1 & $.861 \mathrm{a}$ & .741 & .722 & .32285 \\
\hline
\end{tabular}
\end{tabular}

The above table shows the value of $\mathrm{R}$ square, which is 0.741 , which means that $74 \%$ of dependent variable of retention can be explained by its 3 independent variable i.e. reward, employees' compensation and employees training and development. It also shows that $26 \%$ (100\%-74\%) of DV of retention is explained by other factors.

ANOVA for Public Sector University

\begin{tabular}{lllllll}
\hline \multirow{2}{*}{ Model } & & \multicolumn{2}{l}{ Sum } & of & & \\
& & Squares & df & Mean Square & F & Sig. \\
\hline 1 & Regression & 11.931 & 3 & 3.977 & 38.156 & $.000 \mathrm{a}$ \\
& Residual & 4.169 & 40 & .104 & & \\
& Total & 16.100 & 43 & & & \\
\hline
\end{tabular}

a. Predictors: (Constant), REW, TCD, RWD

b. Dependent Variable: TI

Table above determine satisfactory result. This means that $\mathrm{p}$ value is less than 0.05 , and at $95 \%$ confidence level.

Table 5.7.3Coefficients for public university

\begin{tabular}{|c|c|c|c|c|c|c|}
\hline \multirow[b]{2}{*}{ Model } & & \multicolumn{2}{|c|}{$\begin{array}{l}\text { Unstandardized } \\
\text { Coefficients }\end{array}$} & $\begin{array}{l}\text { Standardized } \\
\text { Coefficients }\end{array}$ & \multirow[b]{2}{*}{$\mathrm{t}$} & \multirow[b]{2}{*}{ Sig. } \\
\hline & & $\mathrm{B}$ & $\begin{array}{l}\text { Std. } \\
\text { Error }\end{array}$ & Beta & & \\
\hline 1 & (Constant) & .347 & .188 & .304 & 1.845 & .070 \\
\hline & $\mathrm{COM}$ & .260 & .129 & .276 & 2.024 & .048 \\
\hline & RWD & .264 & .145 & .348 & 1.821 & .074 \\
\hline & TCD & .313 & .088 & & 3.547 & .001 \\
\hline
\end{tabular}

a. Dependent Variable: TI

There are 3 independent variables in this study (compensation, reward and recognition,training and development). Our alternate hypotheses were, that these 3 variable has association with employees turn over intention(DV). Statistically if $\mathrm{p}<0.05$, then Alternate hypotheseswill be accepted. But here result shows that value of reward and recognition is (.074) has highly insignificant that is $\mathrm{p}>0.05$ at $95 \%$ confidence interval.So statistically in this case $\mathrm{H} 2 \mathrm{a}$ will be rejected and other two hypotheses that is $\mathrm{H} 1 \mathrm{a}$ and $\mathrm{H} 3 \mathrm{a}$ will be accepted. 


\subsection{Empirical results for private sector universities}

Model Summary

\begin{tabular}{lllll}
\hline Model & $\mathrm{R}$ & R Square & $\begin{array}{l}\text { Adjusted } \\
\text { Square }\end{array}$ & $\begin{array}{c}\text { R Std. Error of the } \\
\text { Estimate }\end{array}$ \\
\hline 1 & $.822 \mathrm{a}$ & .676 & .657 & .35204 \\
\hline
\end{tabular}

a. Predictors: (Constant), REW, TCD, COM

The above table summarizes private sector university analysis, the above model showsthe value of $\mathrm{R}$ square, which is 0.676 , which means that $67 \%$ of dependent variable of retention can be explained by its 3 independent variable i.e. reward, employees' compensation and employees training and development. It also shows that $33 \%(100 \%-67 \%)$ of DV of retention is explained by other factors.

ANOVA for private sector

\begin{tabular}{lllllll}
\hline \multirow{2}{*}{ Model } & & \multicolumn{2}{l}{ Sum } & of & & \\
Squares & df & Mean Square & F & Sig. \\
\hline 1 & Regression & 13.424 & 3 & 4.475 & 36.104 & $.000 \mathrm{a}$ \\
& Residual & 6.445 & 52 & .124 & & \\
& Total & 19.868 & 55 & & & \\
\hline
\end{tabular}

a. Predictors: (Constant), REM, TCD, RWD

b. Dependent Variable: TI

Table above determine satisfactory result of private sector universities. As the significance level of the model is not over than 0.05 . Thus, model that used in this research is satisfactory good.

Tabl4 5.8.3 Coefficients for private university

\begin{tabular}{lllllll}
\hline \multicolumn{5}{c}{ Model } & & \multicolumn{5}{c}{ Standardized } \\
\cline { 2 - 5 } & & B & Std. Error & Beta & t & Sig. \\
\hline 1 & (Constant) & .021 & .271 & & .078 & .938 \\
& COM & .085 & .166 & .096 & .514 & .611 \\
& RWD & .594 & .214 & .575 & 2.770 & .009 \\
& TCD & .336 & .137 & .279 & 2.457 & .019 \\
\hline
\end{tabular}

a. Dependent Variable: TI

There are 3 independent variables in this study(compensation, reward and recognition and training and development).our alternate hypotheses states that these 3 variable has association with employees turn over intention(DV).Statistically if $p<0.05$, then Alternate hypotheseswill be accepted. The above model shows that value of compensation is(.611)which is highly insignificantthat isp $>0.05$ at $95 \%$ confidence interval.So statistically in this case $\mathrm{H} 1 \mathrm{~b}$ will be rejected and other two hypotheses that is $\mathrm{H} 2 \mathrm{~b}$ and $\mathrm{H} 3 \mathrm{~b}$ will be accepted having value of (.019) and (.009), which is less than 0.05 . 
5.9 Mean Comparison of Public and Private Sector Universities

\begin{tabular}{lllll}
\hline Model & $\mathrm{R}$ & R Square & $\begin{array}{l}\text { Adjusted } \\
\text { Square }\end{array}$ & $\begin{array}{c}\text { R Std. Error of } \\
\text { the Estimate }\end{array}$ \\
\hline 1 & $.834 \mathrm{a}$ & .696 & .687 & .33776 \\
\hline
\end{tabular}

a. Predictors: (Constant), COM, TCD, RWD

The above model describes the value of $\mathrm{R}$ square, which is 0.696 , which means that $69 \%$ of dependent variable of retention can be explained by its 3 independent variable i.e. reward and recognition, employees compensation and employees training and development. It also shows that $31 \%(100 \%-69 \%)$ of DV of retention is explained by other factors. The result from the ANOVAs analysis shows that the model is satisfactory fit,

Table 5.9.2ANOVA for public \& private universities

\begin{tabular}{llllll}
\hline & Sum & of & Mean & & \\
Model & Squares & df & Square & F & Sig. \\
\hline 1Regression & 25.091 & 3 & 8.364 & 73.311 & $.000 \mathrm{a}$ \\
Residual & 10.952 & 96 & .114 & & \\
Total & 36.043 & 99 & & & \\
\hline
\end{tabular}

a. Predictors: (Constant), COM,TCD,RWD

The result from the ANOVAs analysis shows that model is satisfactory fit.

Table 5.9.3Coefficients for public and private universities

\begin{tabular}{lllllll}
\hline \multicolumn{2}{c}{} & & \multicolumn{2}{l}{$\begin{array}{l}\text { Unstandardized } \\
\text { Coefficients }\end{array}$} & \multicolumn{3}{l}{$\begin{array}{l}\text { Standardized } \\
\text { Coefficients }\end{array}$} & \\
\cline { 3 - 5 } Model & & B & Std. Error & Beta & t & Sig. \\
\hline 1 & (Constant) & .265 & .148 & & 1.789 & .077 \\
& TCD & .322 & .071 & .328 & 4.521 & .000 \\
& RWD & .373 & .114 & .383 & 3.269 & .002 \\
& COM & .191 & .096 & .225 & 1.992 & .049 \\
\hline
\end{tabular}

a. Dependent Variable: TI

The table shows that all three independent variables i.e. compensation, reward, and training and development are highly significant.

The above results show that maximum value of beta points that, which independent variable is mostly inclined or the most significant variable towards (DV). From the table above, the (IV) reward and recognition has the maximum beta value of 0.383 , this mean that the independent variable of reward and recognition hasstronger effect towardthe retention, if compareto others (IV), both at public and private sector universities. This model also proves our fourth hypotheses that HRM factors entail differs in public and private universities. So there for $\mathrm{H} 4$ is supported.

\section{Key Findings}

H1: There is significant relationship between employees Compensation \& employee's turnover intention

From the above findings it is concluded that the (IV) i.e. employees' compensation has positive and significant relationship between (DV) i.e.employees' retention. The derived value 0.049 designate that compensation is positively and significantly associated to retention $(\mathrm{p}<0.05)$. Therefore, $\mathrm{H} 1$ is supported. 
From the literature it is observed that fair and reasonable compensation system is critical to attract and retain top competent employees. if employees get good salary and compensation they get a feeling that they are appreciated by the concerned organization for their work which they perform (Lai, 2011).As a result, they are aggravated to perform better for their organization. When they feel that their work is valued they tend to stay in the organization. In employees' view compensation is not only the achievement of advantages and benefit they receive for their work, but it also imitates their accomplishments (Ali, 2009).

$\mathrm{H} 2$ : There is significant relationship between Reward \& employee's turnover intention.

From the hypotheses testing, concluded that the (IV) i.e. reward and recognition have positive and significant relationship between (DV) i.e. employees' retention. The derived value 0.002 designate reward and recognition is positively and significantly associated to retention ( $\mathrm{p}<0.05)$. Therefore, $\mathrm{H} 2$ is supported.

Some researchers emphasize on the issue of recognition and consider it as most important tool for employee motivation. (Kamal \& Appelbaum 1998; Dutton 1998; David \& Grawitch 2006; Saunderson 2004), giving distinctiveness to their employees and giving meaningful and productive tasks. (Mow 1987; Morin 1996, 2001). certainly, giving recognition to employees help them in personal development and folder vibrant industrial relation. It is also establishing from the previous research that employee recognition is important for employees' intellectual strength. In fact, Brun et al.(2003) found that to be deficient in employees' recognition, it represents the second-largest risk factor because of which employees face psychological distress in the workplace

H3: There is significant relationship between employee's Training \& Development and employee's turnover intention.

From the above findings it is concluded that the (IV) i.e. employees training and development have positive and significant relationship between (DV) i.e. employees' retention. The derived value 0.00 designate that investment in employees training and development is positively and significantly associated to retention and its p-value is 0.00 ( $\mathrm{p}<0.05$ ). Therefore, $\mathrm{H} 3$ is supported.

In order to increase the capability to solve problems, which employees face during their work, job related training plays an important role (Acton\&Golden,2002). Once employees get confidence and motivation to do their task and perform well, it will result in employees' job commitment and will have negative effect on turnover rate. In order to keep employees updated \& confident to current task or operations, organization should provide suitable and appropriate training \& development programs.

All the way through training, employees are capable to work with more commitment and they require little supervision (Mikeal, 2011). In 2009, a study release by APTA (American Public Transportation Association), it recommended that associations must arrange adequate training program for workers maturity to hold employees. Thus, it shows that employee training \& development is imperative and critical for holding workers in any organization.

H4: The impact of HRM practices implies differs across public and private sector universities

However, this study is carried out in both public and private sector universities faculty members. The study shows some interesting facts. The HR practices which are tested here, that is employees' Compensation. Reward and recognition and employees training and development 
Regarding public sector universities, one of the independent variable that is reward and recognition, which is not positively associated with the retention of core employees, our findings suggests that the teaching staff of public sector universities in Khyber Pakhtunkhwa appears not to be motivated by reward and recognition.

This may be due to the organization culture and policies. According to sunail (2003) that there are 3 types of rewards and recognition. One is verbal praise which is done by supervisor and other leaders. The other two are salary increase $\&$ gifts certificates. The required increase in salary shows an employee's performance over the year, effectively achieving their tasks and responsibilities, and the gifts certificates were for local stores, restaurants or movie tickets for their outstanding teamwork and taking extra responsibility for completing the given tasks.

But giving these type of privileges to the employees, it needs a fair rules and regulation and free from favoritism. Some organizations have exhibit feature of discrimination and bias acts which have damaged their representation and aggravated employees to move into new organization. According to Lobel (1996), HR personnel should play an important role to ensure fair handling of all employees needs and wants. Depending on the level of work and work quality, HR personnel must ensure proper salary and wages structure, which is fair and systematic and work out to plan reward system which in result ropes organization norms and culture of equity. While our research regarding faculty members of private sector universities, our research findings shows that, that one of the independent variable that is employee compensation is negatively associated with employee's retention, one of the reasons for this could be that most of the private sector universities are located in develop areas, and employers give much preference to rewards and recognition instead of compensation.

Because in private sector universities job security depends upon achievements of tasks and getting recognition. Most of the private sectors universities have centralize system, some of the factors in private sector universities that effect the retention of employees is management style they have adopt and lack of empowerment to the employees. A significant feature in satisfying the needs of employees is to offer them with a job design \& job description they are satisfied with. The compensation system should also be fair, as designate by research participants. This means that there should be a salary scale that shows that one is paid according to one's job performance. Therefore, there is need to design or create effective compensation strategy, in order to compensate the employees. For intelligence -incentive organization like education institution, it is necessary to design an effective compensation program. Because knowledgeable and proficient employees are the core resources to the organization (Lai, 2011).

\subsection{Implication of the study}

This research investigates how employees recognizes the importance of employee compensation, reward and recognition and employee training and development and their characteristics when they make assessment or decision to stay in an organization. Now a day's these aspects and characteristics are critical and essential HR tools that are often been used by most of the organization to assist their strategic management. Based on the statistical findings, the given end result shows close association between these (IV) \& employee retentions. Therefore, the heads of the organization must be responsive to the needs of employees in learning new skills \& knowledge through training and development, aspiration for recognition and competitive compensation. 
The results of the study assume that, in context of these aspects, if an organization fulfils employee satisfaction, there is a high possibility that the retention rate would improve in that organization. Moreover, this research exposes the prospect for organization to influence these three aspects of HRM to attract and gain potential talents. By creating a good reputation, the organization will straightforwardly become favorites among the workers. In order to increase productivity and gain high value the organization must have skills to motivate its employees' in a coordinated manner.

\subsection{Limitation and future research direction}

The foremost constraint of this study is that, the data was collected through crosssectional framework. Which means the data was collected at a single point in time. Through cross sectional framework, the study might miss, some valuable information regarding the variables, it means if the researcher uses a wholly objective questionnaire; the respondents cannot answer questions involving past events with perfect precision. This either amplifies or lessens the possessions of definite variables, distressing the cross-sectional study's outcomes. So therefore it is suggested that, in order to get steadfast and steady response on the variable, data should be collected through longitudinal framework. Only faculty members of public and private sector universities were targeted, which was another curb of this research. In order to find the causes of turnover, top management of the universities should also be targeted and interviewed. In addition to above, future research should also be conducted to find out the influence of organization factors on the retention of core employees in higher education institutions.

\subsection{Conclusion}

As far as what the current investigation has shown, that there is overall significant association, between the factors of training and development, reward and recognition and employees compensation on employees' retention of public and private sector universities. Factor of reward and recognition is not significantly related to employees' retention in public sector universities, and factor of compensation is not significantly associated to employees' retention at private sector universities, this depicts the major findings of this research, that how different demographic changes which have an impact on employee expectations regarding job satisfaction \& retention. But at the end, by comparing and getting the mean comparison of public and private sector universities, the current study gives pragmatic evidence that independent variables to be significantly affecting the employee retention. Most of the social scientist are of the same opinion with these proclamation as given in literature review by providing all the pragmatic verification, that these factors are positively associated towards employees' retention. Therefore, the devise hypotheses are established according to these researchers' original findings as foundation, awaited to be experienced and tested in later stages through this current study's result. As conclusion, the overall research productively recognizes that training and development, reward and recognition and compensation are critical and fundamental concern for universities teaching staff retention decision. While reward and recognition is less fundamental to teaching staff at public sector, on the other hand compensation is perceived as less fundamental to the teaching staff at private sector universities. These consideration and variation can be attributed to different organization culture and policy.

\section{References}

Acton, T., \& Golden, W. (2002). Training: The way to retain valuable IT employees. In Conference Proceedings, Informing Science (pp. 1-12). 
Appelbaum, S. H., \& Kamal, R. (2000). An analysis of the utilization and effectiveness of non-financial incentives in small business. Journal of Management Development, 19(9), 733-763.

Bassi, L. J., \& Van Buren, M. E. (1999). Valuing investments in intellectual capital. International Journal of Technology Management, 18(5-8), 414-432.

Brun, J. P., Biron, C., Martel, J., \& Ivers, H. (2003). Analysis of workplace mental health programs in organizations. IRSST report A-342.

Delaney, J. T., \& Huselid, M. A. (1996). The impact of human resource management practices on perceptions of organizational performance. Academy of Management journal, 39(4), 949-969.

Eskildsen, J. K., \& Nussler, M. L. (2000). The managerial drivers of employee satisfaction and loyalty. Total Quality Management, 11(4-6), 581-588.

Highhouse, S., Stierwalt, S. L., Bachiochi, P., Elder, A. E., \& Fisher, G. (1999). Effects of advertised human resource management practices on attraction of African American applicants. Personnel Psychology, 52(2), 425-442.

Ichniowski, C., Shaw, K., \& Prennushi, G. (1997). The effects of human resource management practices on productivity: A study of steel finishing lines. The American Economic Review, 291-313.

Lai, E. R. (2011). Motivation: A literature review. Person Research's Report.

Meyer, J. P., \& Allen, N. J. (1991). A three-component conceptualization of organizational commitment. Human resource management review, 1(1), 61-89.

Oakland, S., \& Oakland, J. S. (2001). Current people management activities in worldclass organizations. Total Quality Management, 12(6), 773-788.

Parker, O., \& Wright, L. (2001). Pay and employee commitment: the missing linkThe company that enhances compensation conditions and practices will likely see an improvement in employee commitment. Ivey Business Journal, 65(3), 70-73.

Roodt, G., \& Kotze, K. (2005). Factors that affect the retention of managerial and specialist staff: An exploratory study of an employee commitment model. SA Journal of Human Resource Management, 3(2), 48-55.

Rynes, S. L., \& Barber, A. E. (1990). Applicant attraction strategies: An organizational perspective. Academy of management review, 15(2), 286-310.

Salipante Jr, P., \& Goodman, P. S. (1976). Training, counseling, and retention of the hard-core unemployed.

Saunderson, R. (2004). Survey findings of the effectiveness of employee recognition in the public sector. Public Personnel Management, 33(3), 255-275.

Snell, S. A., \& Dean, J. W. (1992). Integrated manufacturing and human resource management: A human capital perspective. Academy of Management journal, 35(3), 467-504.

Snell, S. A., \& Youndt, M. A. (1995). Human resource management and firm performance: Testing a contingency model of executive controls. Journal of Management, 21(4), 711-737.

Tett, R. P., \& Meyer, J. P. (1993). Job satisfaction, organizational commitment, turnover intention, and turnover: path analyses based on meta- analytic findings. Personnel psychology, 46(2), 259-293.

Whitener, E. M. (2001). Do "high commitment" human resource practices affect employee commitment? A cross-level analysis using hierarchical linear modeling. Journal of management, 27(5), 515-535.

Williams, M. L., \& Dreher, G. F. (1992). Compensation system attributes and applicant pool characteristics. Academy of Management Journal, 35(3), 571-595. 